\title{
Omeprazole may exert both a bacteriostatic and a bacteriocidal effect on the growth of Helicobacter pylori (NCTC 11637) in vitro by inhibiting bacterial urease activity
}

\author{
F Mirshahi, G Fowler, A Patel, G Shaw
}

\begin{abstract}
Aims-To assess the potential antibacterial effect of omeprazole, a benzimidazole proton pump inhibitor, on the growth of Helicobacter pylori in vitro and to evaluate the effect of this compound on bacterial urease activity.

Methods-The growth of $H$ pylori was observed in liquid culture in the presence and absence of omeprazole $(0.8 \mathrm{mg} / \mathrm{ml})$. Urease activity was evaluated in aliquots removed from two hour cultures by monitoring the initial change in absorbency at $560 \mathrm{~nm}$ in the presence of $0.02 \%$ phenol red.

Results-The minimum inhibitory concentration of omeprazole against $\boldsymbol{H}$ pylori was $0.8 \mathrm{mg} / \mathrm{ml}$. The concentration of omeprazole required to inhibit growth was dependent on inoculum density: omeprazole $(0.8 \mathrm{mg} / \mathrm{ml})$ prevented growth from a $1 \times 10^{6} \mathrm{cfu} / \mathrm{ml}$ inoculum, but not from the higher inocula of $10^{7}$ or $10^{8} \mathrm{cfu} / \mathrm{ml}$. This is the first study to demonstrate that omeprazole exerts a bacteriocidal effect against low bacterial densities and a bacteriostatic effect when bacterial density is high. When used at the onset of growth, this concentration of omeprazole has a bacteriocidal effect after four hours, although it exerts a bacteriostatic effect when added to cultures after the exponential phase. Bacterial urease activity is competitively inhibited by omeprazole in a dose dependent manner.

Conclusion-The results suggest that omeprazole exerts both a bacteriocidal and a bacteriostatic effect against $H$ pylori and competitively inhibits bacterial extracellular urease activity

(f Clin Pathol 1998;51:220-224)
\end{abstract}

Keywords: Helicobacter pylori; urease; omeprazole

The School of Health and Sports Science,

The University of

North London,

Holloway Road,

London N7 8DB, UK

F Mirshahi

G Fowler

A Patel

G Shaw

Correspondence to: Dr Shaw.

Accepted for publication 11 November 1997

Peptic ulcer disease is a multifactorial pathological condition. The aetiological role played by acid hypersecretion and/or a failure of the mucosa to generate sufficient protective factors is well established. ${ }^{1}$ Since the discovery of a Gram negative, microaerophilic, curved bacillus in gastric biopsy specimens, ${ }^{2}$ there has been speculation about its role as an additional aetiological factor in peptic ulcer disease. This organism, Campylobacter pylori (now Helicobacter pylori) is now accepted as a major cause of chronic antral gastritis ${ }^{3}$ and gastric cancer. ${ }^{4}$
In particular, $H$ pylori may be responsible for peptic ulcer relapse. ${ }^{5}$

Numerous strategies exist for the treatment of peptic ulcers. Possibly, the most promising agents are those with a dual mechanism of action. One such agent is the benzimidazole compound, omeprazole, which inhibits acid secretion and which may affect the growth of $H$ pylori. Currently available evidence regarding the efficacy of omeprazole as a single agent therapy against $H$ pylor $i$ is inconclusive. It has been suggested ${ }^{6}$ that omeprazole clears the antral mucosa of $H$ pylori infection, although this is not accepted universally. ${ }^{7}$ A previous study ${ }^{8}$ suggested that omeprazole causes temporary suppression rather than true eradication of the organism.

Evidence derived from in vitro susceptibility studies is also inconclusive, suggesting both a bacteriostatic $^{9}$ and a bacteriocidal ${ }^{10}$ effect for benzimidazole compounds against $H$ pylori. Consequently, there is a need to elucidate more fully the nature of the effect of omeprazole on the growth of $H$ pylori in vitro. Recent observations ${ }^{11}$ have suggested that the potent bacterial urease may represent a potential target for the benzimidazole proton pump inhibitors, and that inhibition of this enzyme may provide one explanation for the antibacterial properties of this group of compounds.

The present work reports our preliminary studies to evaluate the antibacterial properties of omeprazole when added to cultures of $H$ pylori type strain NCTC 11637 at different stages of growth, in order to establish a possible bacteriocidal or a bacteriostatic effect of this anti-ulcer agent. Furthermore, we assess the effect of omeprazole on the extracellular urease activity of $H$ pylori.

\section{Methods}

BACTERIAL STRAINS

$H$ pylori strain NCTC 11637 used throughout this study was obtained from The Public Health Laboratory, Colindale, London, UK.

When required, inocula were derived by harvesting $H$ pylori from 72 hour confluent brainheart infusion agar medium plates in brainheart infusion liquid media. The strength of the inoculum was determined using a PetroffHauser counting chamber with subsequent dilutions in brain-heart liquid media.

MEDIA

Brain-heart infusion medium was used $0.25 \%$ (wt $/ \mathrm{vol}$ ) yeast extract, $10 \%$ ( $\mathrm{vol} / \mathrm{vol})$ throughout this study. Solid medium contained 
Table 1 Effect of omeprazole on the growth of Helicobacter pylori derived from a starting inoculum of $1 \times 10^{6} \mathrm{cfu} / \mathrm{ml}$

\begin{tabular}{ll}
\hline Omeprazole concentration $\left(\mathrm{mg} / \mathrm{cm}^{3}\right)$ & $c f u / m l$ \\
\hline 0.0 & $8.9(1.4) \times 10^{5}$ \\
0.2 & $6.8(0.8) \times 10^{5}$ \\
0.4 & $4.5(1.1) \times 10^{5 \star}$ \\
0.8 & $<1 \times 10^{1 \star}$ \\
1.0 & $<1 \times 10^{1}$ \\
\hline
\end{tabular}

Helicobacter pylori was cultured at $37^{\circ} \mathrm{C}$ for five days in an atmosphere of $10 \% \mathrm{CO}_{2}, 5 \% \mathrm{O}_{2}$, and $85 \% \mathrm{~N}_{2}$ on brain-heart infusion agar containing $10 \%$ laked horse blood, $0.25 \%$ yeast extract, $0.4 \%$ supplement SR147E, and a range of omeprazole concentrations.

Values of colony forming units ( $\mathrm{cfu}) / \mathrm{ml}$ are means (SEM) of triplicate determinations.

${ }^{*}$ Comparison of confidence limits showed there to be a significant difference $(\mathfrak{p}<0.01)$ between these values.

Table 2 Effect of bacterial density on the inhibitory effect of omeprazole $(0.8 \mathrm{mg} / \mathrm{ml})$ against Helicobacter pylori

\begin{tabular}{lll}
\hline $\begin{array}{l}\text { Inoculum } \\
\text { density } \\
\text { (cfulml) }\end{array}$ & \multicolumn{2}{l}{ Bacterial growth $(c f u / m l)$} \\
\cline { 2 - 3 } & Solvent alone & Solvent + omeprazole \\
\hline $1 \times 10^{6}$ & $8.7(1.1) \times 10^{5}$ & $<1 \times 10^{1}$ \\
$1 \times 10^{7}$ & $>1 \times 10^{6}$ & $2.1(0.5) \times 10^{4}$ \\
$1 \times 10^{8}$ & $>1 \times 10^{6}$ & $2.5(0.3) \times 10^{4}$ \\
\hline
\end{tabular}

Helicobacter pylori was cultured at $37^{\circ} \mathrm{C}$ for five days in an atmosphere of $10 \% \mathrm{CO}_{2}, 5 \% \mathrm{O}_{2}$, and $85 \% \mathrm{~N}_{2}$ on brain-heart infusion agar containing $10 \%$ laked horse blood, $0.25 \%$ yeast extract, $0.4 \%$ supplement SR147E, and a range of omeprazole concentrations.

Values of colony forming units (cfu)/ml are means (SEM) of triplicate determinations.

laked horse blood, $0.4 \%$ (vol/vol) supplement SR147E (Oxoid, Basingstoke, UK), and 1.3\% agar. Liquid medium contained $0.25 \%$ (wt $/ \mathrm{vol}$ ) yeast extract, $10 \%$ (vol/vol) horse serum, and $0.4 \%$ (vol/vol) $H$ pylori supplement SR147E (Oxoid).

PROTON PUMP INHIBITOR

A stock solution of omeprazole (Astra Hassle, Molndal, Gothenburg, Sweden) was freshly prepared in dimethyl sulphoxide (DMSO) each day to give the required concentration.

DETERMINATION OF THE MINIMUM INHIBITORY CONCENTRATION OF OMEPRAZOLE

A $100 \mu \mathrm{l}$ aliquot of a $1 \times 10^{6}$ colony forming units (cfu)/ml inoculum was added in triplicate to brain-heart infusion agar plates containing variable $(0-1.0 \mathrm{mg} / \mathrm{ml})$ concentrations of omeprazole. The omeprazole stock solution $(50 \mathrm{mg} / \mathrm{ml})$ was prepared freshly each day by dissolving the compound in DMSO followed by filter sterilisation. Aliquots $(1 \mathrm{ml})$ containing variable concentrations of omeprazole were then added to molten $\left(45^{\circ} \mathrm{C}\right)$ agar to give a final concentration range of $0-1.0 \mathrm{mg} / \mathrm{ml}$. Solvent alone was added to control plates, giving a final concentration of $2 \%$.

Once inoculated, all plates were incubated for five days at $37^{\circ} \mathrm{C}$ in an atmosphere of $10 \%$ $\mathrm{CO}_{2}, 5 \% \mathrm{O}_{2}$, and $85 \% \mathrm{~N}_{2}$ and the effect of omeprazole on the growth of $H$ pylori was determined. For the purpose of this study, the minimum inhibitory concentration of omeprazole was defined as the lowest concentration of omeprazole that prevented any visible growth.

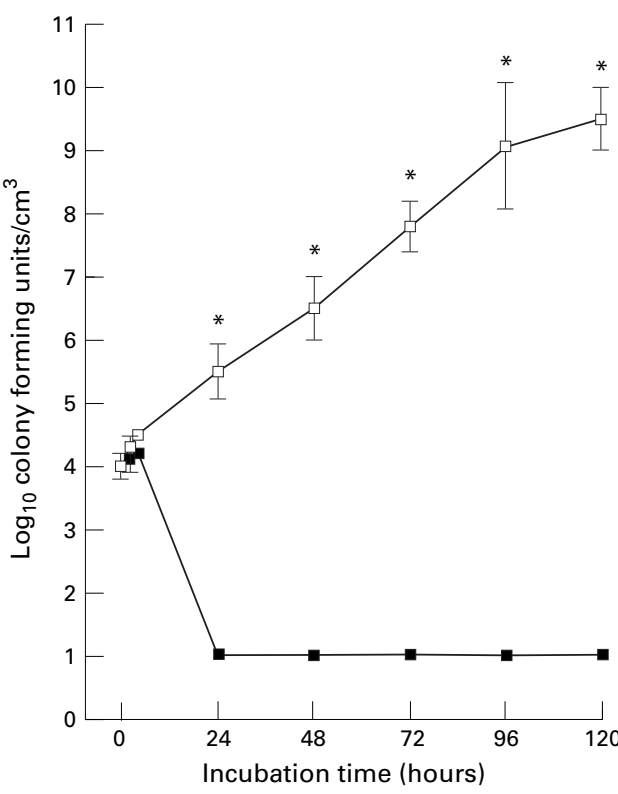

Figure 1 Growth kinetics of Helicobacter pylori in brain-heart infusion broth containing $0.25 \%$ (wt/vol) yeast extract, $10 \%$ (vol/vol) horse sera, and $0.4 \%$ (vollvol) $H$ pylori supplement SR147E. Test flasks (closed symbols) contain $0.8 \mathrm{mg} / \mathrm{ml}$ omeprazole added at the onset of growth and control flasks (open symbols) contain solvent ( $2 \%$ vollvol DMSO) alone. Viability was determined at 0, 2, 4, $24,48,72,96$, and 120 hours and the results are expressed as mean (SEM) of six determinations. A significant difference $\left({ }^{*} p<0.05\right)$ between test and control data was determined by one way analysis of variance.

EFFECT OF BACTERIAL DENSITY ON THE IN VITRO EFFICACY OF OMEPRAZOLE

A $100 \mu \mathrm{l}$ aliquot derived from each of the starting inocula $\left(1 \times 10^{6}, 1 \times 10^{7}\right.$, and $\left.1 \times 10^{8} \mathrm{cfu} / \mathrm{ml}\right)$ was added in triplicate to brain-heart infusion agar medium containing $0.8 \mathrm{mg} / \mathrm{ml}$ of omeprazole. Solvent ( $2 \%$ vol/vol DMSO) alone was added to control agar.

Once inoculated, all plates were incubated for five days at $37^{\circ} \mathrm{C}$ in an atmosphere of $10 \%$ $\mathrm{CO}_{2}, 5 \% \mathrm{O}_{2}$, and $85 \% \mathrm{~N}_{2}$ and viability was determined by colony counts.

THE EFFECT OF OMEPRAZOLE ON THE GROWTH OF H PYLORI

An $H$ pylori inoculum was prepared $\left(\sim 1 \times 10^{6}\right.$ $\mathrm{cfu} / \mathrm{ml}$ ) in brain-heart infusion broth and $1 \mathrm{ml}$ was added to two sets of triplicate flasks, one set containing $50 \mathrm{ml}$ of the same medium plus omeprazole $(0.8 \mathrm{mg} / \mathrm{ml}$; previously shown to be the minimum inhibitory concentration, $\mathrm{pH}$ 6.9), and one set of control flasks containing medium and solvent only (total volume $50 \mathrm{ml}, \mathrm{pH}$ 6.9). Following inoculation, each flask was incubated at $37^{\circ} \mathrm{C}$ in an atmosphere of $10 \% \quad \mathrm{CO}_{2}, 5 \% \quad \mathrm{O}_{2}$, and $85 \% \quad \mathrm{~N}_{2}$, with continuous agitation $(100 \mathrm{rpm}, \mathrm{G} 25$ incubator shaker; New Brunswick Scientific, Edison, New Jersey, USA). Samples $(100 \mu \mathrm{l})$ were removed from both sets of broth cultures after two and four hours incubation and then at regular 12 hour intervals for five days to establish viability. Additional samples $(1 \mathrm{ml})$ were removed at two hours to determine urease activity and at 36 hour intervals to measure $\mathrm{pH}$. To determine the number of viable bacteria at each time point, serial dilutions of each 


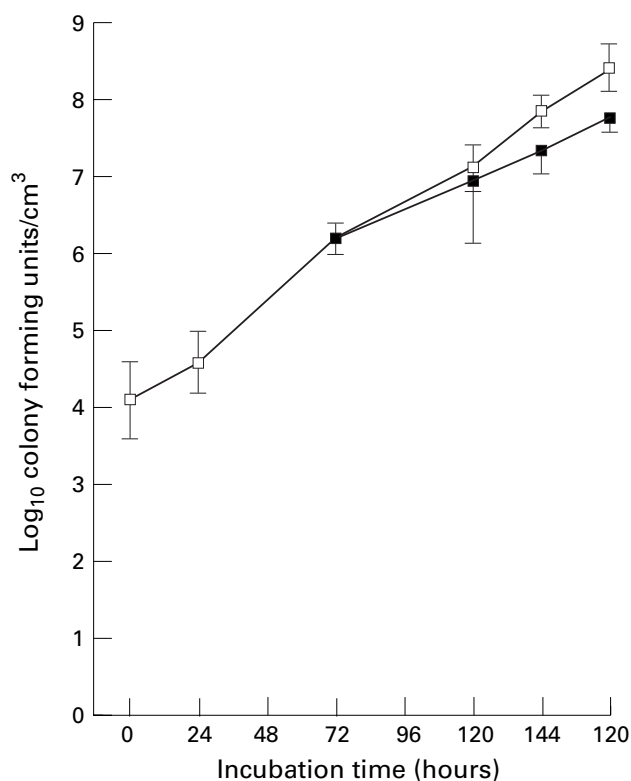

Figure 2 Growth kinetics of Helicobacter pylori in brain-heart infusion broth containing $0.25 \%$ (wt/vol) yeast extract, $10 \%$ (vol/vol) horse serum, and $0.4 \%$ (vol/vol) $H$ pylori supplement SR147E. Test flasks (closed symbols) contain $0.8 \mathrm{mg} / \mathrm{ml}$ omeprazole added on the third day after the exponential phase of growth; solvent ( $2 \% \mathrm{vol} / \mathrm{vol}$

$D M S O)$ alone was added at the same time to control flasks (open symbols). Viability was determined at 0, 24, 48, 72, $96,120,144$, and 168 hours and the results are expressed as mean (SEM) of six determinations.

aliquot were made in sterile saline $(0.9 \%$ $\mathrm{NaCl}$ ) and $100 \mu \mathrm{l}$ added to the surface of brain-heart infusion agar medium. These plates were incubated for five days at $37^{\circ} \mathrm{C}$ in an atmosphere of $10 \% \mathrm{CO}_{2}, 5 \% \mathrm{O}_{2}$, and $85 \%$ $\mathrm{N}_{2}$ and the growth rate of $H$ pylori in the presence and absence of omeprazole $(0.8 \mathrm{mg} / \mathrm{ml})$ was established. Duplicate experiments were performed and, because two way analysis of variance showed no significant difference between experiments, the data are presented as mean (SEM) from six determinations. A significant difference $(p<0.05)$ between test and control data was determined by one way analysis of variance.

A parallel study was carried out with omeprazole $(0.8 \mathrm{mg} / \mathrm{ml})$ added to the test flasks after three days of bacterial growth, that is, after the onset of exponential growth.

EFFECT OF OMEPRAZOLE ON THE UREASE ACTIVITY OF $H$ PYLORI

Bacterial cells were removed from a two hour liquid culture grown in the presence and absence of omeprazole $(0-0.8 \mathrm{mg} / \mathrm{ml})$ and washed twice in phosphate buffer $(50 \mathrm{mM}$, $\mathrm{pH}$ 6.8). This washed, whole cell preparation was used as a source of enzyme throughout. A reaction mixture containing $0.02 \%$ phenol red and urea $(0-6 \mathrm{mM})$ was prepared in $50 \mathrm{mM}$ phosphate buffer ( $\mathrm{pH}$ 6.8) and the reaction was started by the addition of $50 \mu \mathrm{l}$ of the washed, whole cell preparation. Urease activity was determined at $43^{\circ} \mathrm{C}$ by monitoring the initial change in absorbency at $560 \mathrm{~nm}$ against a jack bean urease standard (12 $500 \mu \mathrm{M}$ units/ g). One micromolar unit of enzyme activity will liberate $1.0 \mu \mathrm{mol}$ of ammonium/minute. The

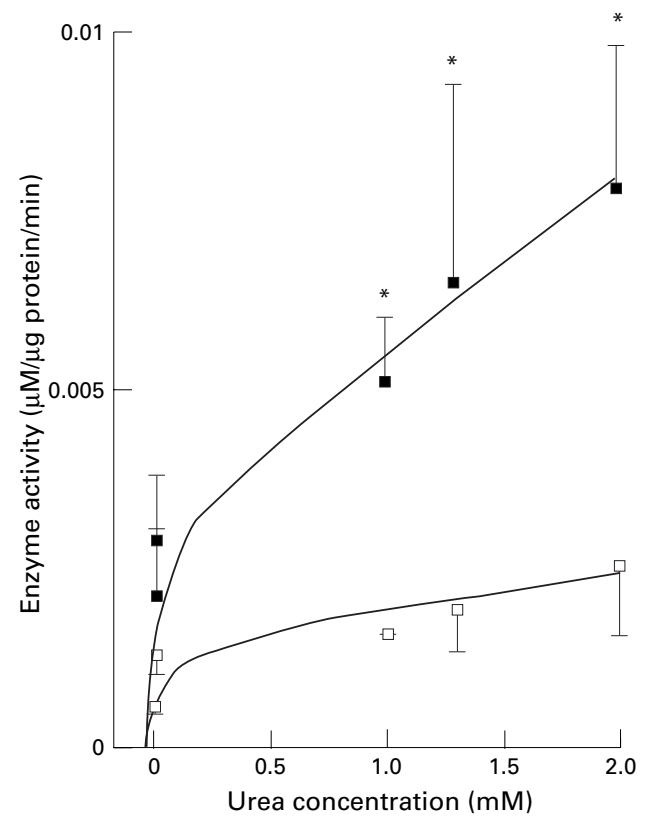

Figure 3 The relation between urease activity of Helicobacter pylori removed from two hour cultures grown in the presence (open symbols) and absence (closed symbols) of omeprazole $(0.8 \mathrm{mg} / \mathrm{ml})$. Data are presented as the mean (SEM) of six determinations.

protein content of the urease preparation was determined using the method of Lowry and colleagues. ${ }^{12}$

\section{Results}

DETERMINATION OF THE MINIMUM INHIBITORY CONCENTRATION OF OMEPRAZOLE

In this study, the minimum inhibitory concentration of omeprazole against $H$ pylori was established as $0.8 \mathrm{mg} / \mathrm{ml}$ (table 1 ).

In addition, the concentration of omeprazole required to inhibit growth was shown to be dependent on inoculum density because omeprazole $(0.8 \mathrm{mg} / \mathrm{ml})$ prevented growth from a $1 \times 10^{6} \mathrm{cfu} / \mathrm{ml}$ inoculum, but not from the higher inocula of $10^{7}$ or $10^{8} \mathrm{cfu} / \mathrm{ml}$ (table 2).

EFFECT OF OMEPRAZOLE ON THE GROWTH OF $H$ PYLORI

Under the standard growth conditions used throughout this study, $H$ pylori typically had a growth rate of $\sim 0.14(0.01) \mathrm{cfu} / \mathrm{hour}$ and a cell generation time of $4.8(0.5)$ hours. Other workers have reported cell generation times for $H$ pylori when grown in supplemented brucella broth of 3.6 hours $^{13}$ and 2.7 hours. ${ }^{14}$

Growth kinetics of $H$ pylori in the presence and absence of omeprazole were evaluated in brain-heart infusion broth with a relatively small starting inoculum $\left(\sim 1 \times 10^{6} \mathrm{cfu} / \mathrm{ml}\right)$. Figure 1 shows a representative growth pattern in which there is an immediate onset of exponential growth under control conditions. When grown in the presence of omeprazole $(0.8 \mathrm{mg} / \mathrm{ml}), H$ pylori has a similar initial growth pattern, although exponential growth was only maintained for four hours before the microbial population quickly declined (fig 1). 


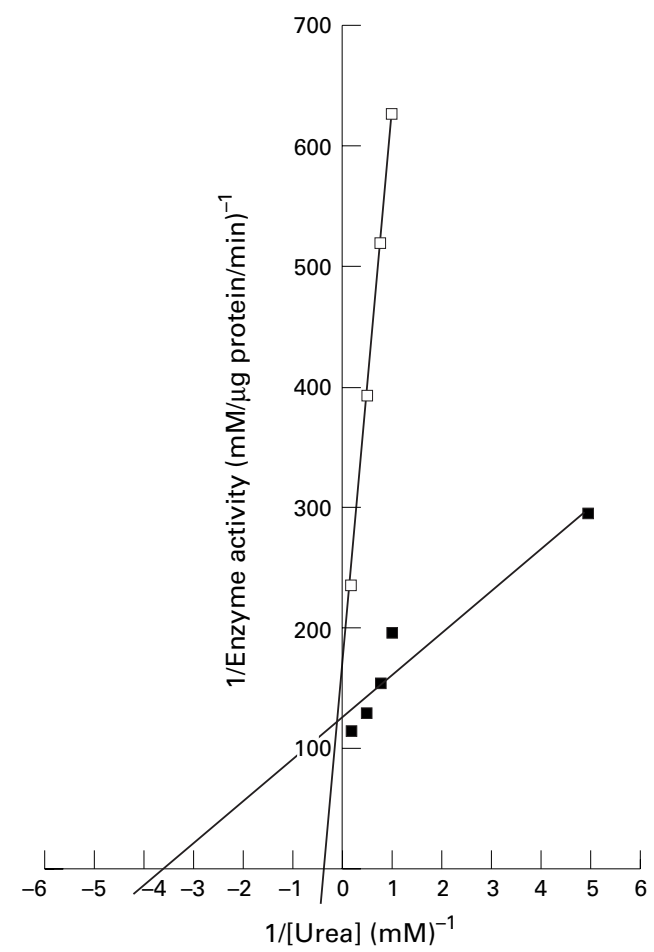

Figure 4 Lineweaver-Burk plot. The relation between $1 /$ urease activity and 1/substrate concentration. Data in the presence (open symbols) and absence (closed symbols) of omeprazole $(0.8 \mathrm{mg} / \mathrm{ml})$ are presented as the mean of six determinations.

When omeprazole was added to the growing culture at 72 hours, a consistent although not significant reduction in growth was observed (fig 2).

EFFECT OF OMEPRAZOLE ON THE UREASE ACTIVITY OF $H$ PYLORI

Under the conditions used in this assay, $H$ pylori urease activity exhibits hyperbolic kinetics with respect to urea concentration (fig 3). The rate of urea degradation was proportional to the concentration of urea, up to $0.1 \mathrm{mM}$ (fig 3 ), and was constant over the incubation period for at least 20 minutes. At all the substrate concentrations tested, the urease activity of bacteria grown in the presence of omeprazole was lower than that found in control bacteria (fig 3). At concentrations of urea above $1 \mathrm{mM}$, this reduction is significant $(\mathrm{p}<0.05)$. LineweaverBurk analysis of the data (fig 4) indicated that control urease activity exhibited a $\mathrm{Km}$ of $0.28 \mathrm{mM}$, which was increased to $2.9 \mathrm{mM}$ in bacteria grown in the presence of omeprazole $(0.8 \mathrm{mg} / \mathrm{ml})$. The extent of this inhibition is proportional to omeprazole concentration up to $0.4 \mathrm{mg} / \mathrm{ml}$ (fig 5). The $\mathrm{Ki}$ value for urea degradation in the presence of omeprazole was calculated to be $0.25 \mathrm{mM}$.

\section{Discussion}

By investigating the effect of omeprazole on the growth of $H$ pylori NCTC 11637 in vitro, this study was able to test for a direct action of omeprazole on $H$ pylori, rather than an antibacterial action mediated by a reduction in acid secretion. In this study, we have established that the effect of omeprazole on $\mathrm{H}$ pylori

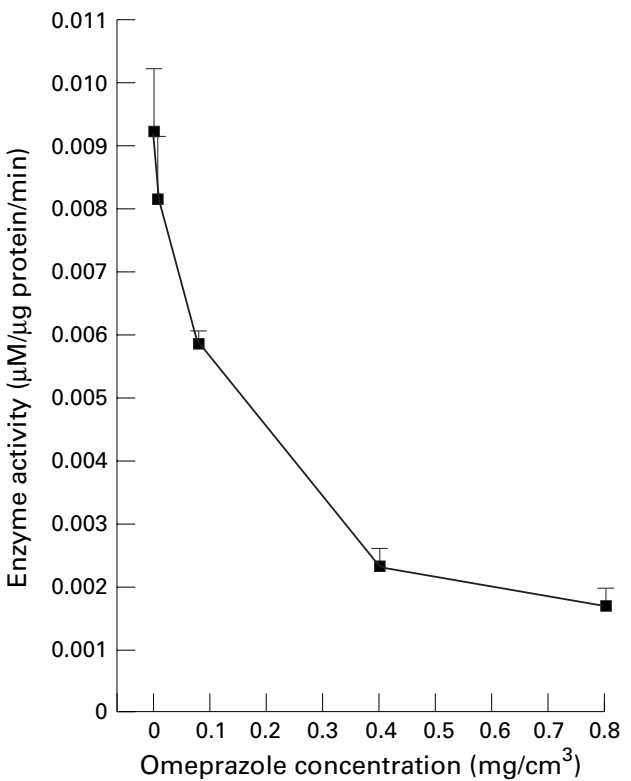

Figure 5 The relation between urease activity and omeprazole concentration over the range $0-0.8 \mathrm{mg} / \mathrm{ml}$ and at a concentration of $2 \mathrm{mM}$ urea. Data are presented as mean (SEM) of six determinations.

is concentration dependent. This concentration dependent effect of omeprazole is particularly significant because we cannot be certain of the drug concentration within the gastric/ duodenal microenvironment occupied by $H$ pylori. Furthermore, we have established the minimum inhibitory concentration of omeprazole against $H$ pylori to be $0.8 \mathrm{mg} / \mathrm{ml}$. This result suggests that omeprazole at $0.8 \mathrm{mg} / \mathrm{ml}$ is capable of exerting a direct antibacterial action on this strain of $H$ pylori in vivo. This effect of omeprazole is not mediated by changes in the $\mathrm{pH}$ of the medium, which remained neutral throughout the culture period, thereby suggesting that the drug was not acid activated. Helicobacter pylori grows well at this $\mathrm{pH}$ because it is adapted to live below the mucous layer, where the $\mathrm{pH}$ is also approximately neutral. ${ }^{15}$ Helicobacter pylori is known to be capable of replication over the $\mathrm{pH}$ range $6.9-8.0 .{ }^{16}$ Other studies $^{10}{ }^{17}$ have suggested lower minimum inhibitory concentrations for omeprazole against $H$ pylori, although direct comparison is difficult because the bacteriocidal effect of omeprazole in vivo is influenced by both the $\mathrm{pH}$ of the medium and the content of fetal calf serum. ${ }^{18}$

This antibacterial effect of omeprazole is dependent on bacterial density because omeprazole $(0.8 \mathrm{mg} / \mathrm{ml})$ fails to reduce growth completely when inocula of $1 \times 10^{7} \mathrm{cfu} / \mathrm{ml}$ and above are used. This study suggests that when challenged with a small inoculum $\left(1 \times 10^{6}\right.$ $\mathrm{cfu} / \mathrm{ml}$ or below), omeprazole $(0.8 \mathrm{mg} / \mathrm{ml})$ has a bacteriocidal effect on the growth of $H$ pylori, which takes effect in four hours. The data presented in this study are supported by other workers, ${ }^{10}$ who have demonstrated a bacteriocidal action of the proton pump inhibitor lansoprazole when used against $H$ pylori NCTC 11637 in vitro at a concentration of $0.1 \mathrm{mg} / \mathrm{ml}$. 
Furthermore, a bacteriostatic effect of both lansoprazole and omeprazole has also been demonstrated when used at lower concentrations in vitro, ${ }^{10}$ or against high density growth, as in this study. When added to established cultures of $H$ pylori, omeprazole only reduces, although not significantly, the microbial population. To our knowledge this is the first study to show a density dependent dual effect of omeprazole.

It is our opinion that omeprazole exerts a bacteriocidal effect on $H$ pylori when used either at raised concentrations or against a small number of organisms. These circumstances may be present within the gastric/ duodenal mucosa during the early stages of an infection or as a consequence of combined antibiotic therapy. Therefore, under such circumstances, omeprazole might be able to eradicate the organism in vivo. Alternatively, omeprazole may exert a bacteriostatic effect, as suggested in this study and by others, ${ }^{9}$ when used against large numbers of organisms, as would be present in more chronic pathological conditions or against established infections. Under these circumstances, omeprazole might only suppress the growth of the organism and not effect complete eradication, thereby providing one possible explanation for peptic ulcer relapse.

The effect of proton pump inhibitors on the urease activity of $H$ pylori has been studied extensively, ${ }^{19}{ }^{20}$ although kinetic data are sparse. In this study, we have shown that omeprazole competitively inhibits the extracellular urease enzyme of $H$ pylori in a dose dependent manner. Urease activity is inhibited by $78 \%$ in the presence of $0.8 \mathrm{mg} / \mathrm{ml}$ omeprazole. Although this enzyme is known to be essential for bacterial colonisation of the gastric mucosae in vivo, and is therefore a potential target for antibacterial agents, the fact that the growth of urease negative mutants of $H$ pylori is also inhibited by omeprazole ${ }^{21}$ indicates that the enzyme itself is not a lethal target for this drug in vitro and other potential targets must exist. It is likely that the omeprazole mediated inhibition of urease may render the organism susceptible to other agents. ${ }^{10}$ Thus, the effects of omeperazole on bacterial growth in vitro may be independent of the ability of this benzimidazole compound to inhibit urease activity. In this study, we have presented data on the effect of omeprazole on the growth of the type strain NCTC 11637 at neutral $\mathrm{pH}$ in vitro and suggest that this proton pump inhibitor may exert both a bacteriostatic and a bacteriocidal effect. However, because different clinical isolates of $H$ pylori are effected to differing extents by proton pump inhibitors, ${ }^{10}$ it is difficult to extrapolate these observations to other strains of this organism.

However, it is our opinion that in order for omeprazole to exert an optimal antibacterial effect it must be used during the early stage of infection when bacterial numbers are low.

This investigation was carried out with the aid of an award from The Astra Foundation. We are extremely grateful for the helpful comments of Dr P Matewele.

1 Hollander HF. The two-component mucous barrier. Arch Intern Med 1954;94:107-20.

2 Warren JR. Unidentified curved bacilli on gastric epithelium in active chronic gastritis. Lancet 1983;i:1273.

3 Coghlan JG, Gilligan D, Humphries H, et al. Campylobacter pylori and recurrence of duodenal ulcers-a 12-month follow-up study. Lancet 1987;ii:1109-11.

4 Forman D, Webb P, Newell D, et al. An international association between Helicobacter pylori infection and gastric cancer. Lancet 1993;341:1359-62.

5 Rauws EAJ, Tytgat GNJ. Cure of duodenal ulcer associated with eradication of Helicobacter pylori. Lancet 1990;335: 1233-5.

6 Mainguet P, Delmee M, Debongnie JC. Omeprazole, Campylobacter pylori and duodenal ulcer. Lancet 1989;ii: 389-90.

7 Rauws EAJ, Langenberg W, Bosma A, et al. Lack of eradication of Helicobacter pylori after omeprazole. Lancet 991;337:1093.

8 Weil J, Bell DG, Powell K, et al. Omeprazole and Helicobacter pylori: temporary suppression rather than true eradication. Aliment Pharmacol Therap 1991;5:309-13.

9 Megraud F, Boyanova L, Lamouliatte H. Activity of lansoprazole against Helicobacter pylori. Lancet 1991;337: 1486.

10 Iwahi T, Satoh H, Masafumi N, et al. Lansoprazole, a novel benzimidazole proton pump inhibitor, and its related compounds have selective activity against Helicobacter pylori. Antimicrob Agents Chemother 1991;35:490-6.

11 Nagata K, Satoh H, Iwahi T, et al. Potent inhibitory action of the gastric proton pump inhibitor lansoprazole against urease activity of Helicobacter pylori: unique action selective for H. pylori cells. Antimicrob Agents Chemother 1991;34: for H. pylo

12 Lowry O, Rosebrough NJ, Farr LA, Randell RJ. Protein measurement with the folin phenol reagent. $f$ Biol Chem 1951;193:265-75.

13 Morgan DR, Freedman R, Depew CE, et al. Growth of Campylobacter pylori in liquid media. $\mathcal{f}$ Clin Microbiol 1987;25:2123-5.

14 Eaton KA, Brooks CL, Morgan DR, et al. Essential role of urease in pathogenesis of gastritis induced by Helicobacter pylori in gnotobiotic piglets. Infect Immun 1991;59:2470-5.

15 Collins JSA. Role of Helicobacter pylori in gastritis and duodenitis in man. Agents Actions [special conference issue]. 1992:C47-9.

16 Goodwin CS, Armstrong JA, Marshall BJ. Campylobacter pyloridis, gastritis and peptic ulceration. F Clin Pathol pyloridis, gastrit

17 Midolo PD, Turnbridge JD, Lambert JR. Bacteriocidal activity and synergy studies of proton pump inhibitors and antibiotics against Helicobacter pylori in vitro. $\mathcal{F}$ Antimicrob Chemother 1997;39:331-7.

18 Sjostrom JE, Fryklund J, Kuhler T, et al. In vitro antibacterial activity of omeprazole and its selectivity for Helicobacter spp. are dependent on incubation conditions. Antimicrob Agents Chemother 1996;40:621-6.

19 Kuhler TC, Fryklund J, Bergman NA, et al. Structureactivity relationship of omeprazole and analogues as Helicobacter pylori urease inhibitors. F Med Chem 1995;38: 4906-16.

20 Figura N, Crabtree JE, Dattilo M. In vitro activity of lansoprazole against Helicobacter pylori. $\mathcal{F}$ Antimicrob Chemother prazole against He

21 Bugnoli M, Bayeli PF, Rapuoli R, et al. Inhibition of Helicobacter pylori urease by omeprazole. Eur $\mathcal{f}$ Gastroenterol Hepatol 1993;5:683-6. 